\title{
Industrialiseringens semantiske felt
}

\author{
Jeppe Nevers: \\ Det Produktive Samfund - 6 kapitler af \\ industrialiseringens idébistorie \\ Syddansk Universitetsforlag, 2013 \\ 208 sider, $298 \mathrm{kr}$.
}

Hobsbawm er død, længe leve Hobsbawm! Med sin seneste bog Det Produktive Samfund - 6 kapitler af industrialiseringens idébistorie har Jeppe Nevers fra et begrebshistorisk perspektiv genfortalt anden del af den Hobsbawmske idé om at den moderne verden er formet ud af en dobbeltrevolution: en politisk og en industriel/teknologisk. I 2011 kom Nevers med sin bog om demokratibegrebets historie fra skeceldsord til slagord. Nu får vi så industrialiseringens historie fra cirka år $1750 \mathrm{og}$ frem til et sted sidst i det 20. århundrede. Som Nevers rigtigt skriver kan ingen være i tvivl om at den proces vi kalder industrialiseringen har efterladt sig tydelige spor $\mathrm{i}$ landskabet og den materielle verden, men "mindre kendt er det, at udviklingen af industrisamfundet også har sat sig dybe spor i vores mentale kulturarv" (s. 12). Det er netop bogens ærinde at vise at industrialiseringen, på samme måde som den politiske tænkning $\mathrm{i}$ samme periode, har en intellektuel historie som er indskrevet i vore dages politisk-sociale sprog.

At fortælle industrialiseringens historie er imidlertid ingen simpel sag. Der må afgrænses og udvælges. Med udgangspunkt $\mathrm{i}$ begrebshistorien, har Nevers inddelt bogen i seks kapitler der hver er centreret omkring hovedbegreber i det betydningskompleks som industrialiseringen, eller det industrielle samfund, udgør. De to modsatrettede holdninger vi genkender som henholdsvis kritikken og begejstringen af den industrielle produktion og maskineriet, er derfor omdrejningspunkt for de to første kapitler. Det tredje kapitel handler om socialismebegrebet som tager form i en gensidig påvirkning af industrisamfundets udvikling, og som derved også skal vise industrialiseringens virkning på moderne politisk teori og sprogbrug. I forlængelse heraf handler fjerde kapitel om 'det sociale 
spørgsmål' som var centralt i udviklingen af et begreb om velfærdsstaten. Kapitel fem omhandler ledelsesbegrebet som får betydning i forbindelse med forskellige ideer om styrring af produktionen, og derved er vi fremme ved sjette og sidste kapitel om produktivitetsbegrebet.

Selv om kapitlerne altså er udvalgt ud fra hvad vi kunne kalde det semantiske felt som Nevers identificerer omkring ideen om det industrielle samfund, og altså ikke i udgangspunktet efter kronologi, forekommer der alligevel en bevægelse i tid efterhånden som kapitlerne skrider frem. Tyngden i de første kapitler er primært på tiden i og omkring 1850 til 1900, mens det sidste kapitel har hovedvægten på 1930erne og frem, med Socialdemokratiet som omdrejningspunkt. Denne kombination af den tematiske og kronologiske opbygning er vellykket udført.

Det Produktive Samfund er skrevet, får vi at vide, på opfordring af Karl Pedersens og Hustrus Industrifond som har til formål at styrke dansk industri, men er ikke af den grund en historie om den danske industrialisering. For Nevers er Danmark den prisme han fortæller sine dele af industrialiseringens historie igennem, og han vil sætte de danske eksempler han graver frem ind i en bredere europæisk kontekst. Det er netop en af styrkerne ved begrebshistorien at den åbner op for at studere overførelser af begreber fra én kontekst (i denne sammenhæng oftest England) til en anden kontekst hvor de skal tilpasses og inkorporeres i de specifikke diskussioner der gjorde sig gældende her. Det lykkedes for det meste for Nevers at finde balance mellem den brede europæiske og den mere snævre danske kontekst således at de gensidigt forstærker hinanden. Eksempelvis i kapitlet om ledelsesbegrebet hvor vi bliver introduceret til Walter Engel der var en central aktør formidlingen af Frederick W. Taylors ideer om Scientific Management ind i en dansk kontekst i de første årtier af 1900-tallet.

Konsekvensen af at ville fortælle en så stor og mangesidet fortælling gennem en række danske eksemplar, på blot 200 sider, kan være at fremstillingen får præg af at være nedslag i enkelte cases som ikke bindes tydeligt nok sammen, og at bogen derfor kan få karakter af at være fragmentarisk. Her slipper Nevers rimeligt godt igennem ved netop at basere sit valg af kapitler ud fra et snit $\mathrm{i}$ industrialiseringens mange betydningslag. Nedslagene behøver ikke at blive relateret direkte til hinanden, fordi de hver især blot skal vise de forskellige lag som ideen om industrisamfundet består af og som hver har sin egen historie. Samtidig synes det nogle gange som om der er meget mere til den enkelte 
case end hvad Nevers har plads til at vise os. For eksempel kan man $i$ andet kapitel læse om det lille skrift Om Industrie og Midler til dens Befordring af Joachim Brandis fra 1812, hvis titel, fra en nutidig betragtning, måske kan overraske derved at den indeholdt en kritik af den begyndende fabriksproduktion. Det begreb om Industrie som skulle befordres var grundet $i$ en mere traditionel forestilling om national flid. Industri og fabrik var altså hinandens modbegreber (s. 33). Brandis' historie syntes at gemme på en langt større debat som han deltog $i$, men som vi på grund af begrænsning i sidetal desværre ikke får skitseret fuldstændig. Sådanne tilfælde må jo så tjene som en opfordring til opfølgning.

En kritik som kunne rejses mod bogen er at muligheden for at nuancere de gængse fortællinger som de fleste af os kender om industriens fremkomst i det moderne samfund, desværre ikke altid bliver udnyttet tilstrækkeligt. For eksempel bliver den stemme, som får lov at markere den skepsis overfor industrien som så ofte kommer til udtryk som en modstilling mellem land og by, den konservative forfatter Jacob Paludan. Den konservative er næsten stereotypen på den maskinkritiske holdning og måske det havde klædt kapitlet at vise tydeligere at land/by-dikotomien gjorde sig gældende på tværs af ideologiske ståsteder; for eksempel den venstreorienterede Mogens Klitgaard som i sin debutroman Der Sidder en mand $i$ en sporvogn (1937) udtrykker præcis samme lede ved storbyen, og lader sin hovedperson tage en tur på landet, væk fra fabrikker, trafik og larm. Man kan selvfølgelig altid pege på flere eksempler og det er klart nok nemt som anmelder at pege på bagefter, men en smule mere nuance her ville måske have blødt op for den kritik/begejstring modstilling som så ofte bliver trukket meget skarpt op og tildelt begreber som kunne tænkes at skygge for nogle af de forestillinger og forventninger der var på færde $\mathrm{i}$ fortiden.

Det Produktive Samfund er skrevet til et bredt publikum og altså ikke alene til faghistorikere og idehistorikere. Og den skal naturligvis også bedømmes derefter. Nevers er en glimrende formidler og udfylder til fulde sin rolle som man klart fornemmer han tager alvorligt. Samtidig, som så tit med rigtig velformidlede tekster, er der også noget at komme efter som fagnørd, ved blandt andet at lade sig inspirere til at strukturere sin historiske fremstilling ud fra de lag af betydninger der uvægerligt vil ligge $i$ ens genstandsfelt. Endelig 
skal den fantastisk flotte indpakning bogen er givet bemærkes. Nevers har fået lov at medtage ganske mange illustrationer som er gengivet $\mathrm{i}$ flot farvekvalitet. Alt i alt en god og gennemarbejdet bog.

Thomas Palmelund Johansen 